\title{
Duodenum and Ampulla of Vater Neuroendocrine Tumor pT4 TNM Finding v8
}

National Cancer Institute

\section{Source}

National Cancer Institute. Duodenum and Ampulla of Vater Neuroendocrine Tumor pT4

TNM Finding v8. NCI Thesaurus. Code C135070.

Duodenum and ampulla of Vater neuroendocrine tumor invading the visceral peritoneum (serosa) or other organs. (from AJCC 8th Ed.) 